\title{
Modeling the biogeochemistry of sulfur in beech (Fagus sylvatica L.) stands of the Vienna Woods
}

\author{
Klaus Dolschak ${ }^{1} \cdot$ Torsten W. Berger $^{1} \mathbb{C}$
}

Received: 12 December 2019 / Accepted: 2 April 2020 / Published online: 12 May 2020

(c) The Author(s) 2020

\begin{abstract}
In this article, we describe the setup and the application of a novel Sulfur Dynamics Model (SDM), with the aim to identify and quantify processes, which are crucial for the understanding of the biogeochemical sulfur (S) cycle of forest ecosystems. The simulator takes into account abiotic processes as well as biotic interactions between atmosphere, plant and soil. We applied the model to two Austrian beech stands where deposition of $\mathrm{S}$ and soil solution chemistry were monitored intensively over a two-year period. Under consideration of high historic loads and the more recent recession of atmospheric $\mathrm{S}$ deposition, we found a suitable model configuration where it was possible to assign both intra-annual fluctuations of the $\mathrm{SO}_{4}-\mathrm{S}$ in soil solution and long-time trends in the stream discharge to specific $\mathrm{S}$ transformation processes. We identified the interplay of microbial immobilization (the microbial conversion of solute sulfate to organic soil S) and mineralization as key driver of short-term fluctuations in the soil solution. In the long term, the delayed release of historically accumulated $\mathrm{S}$ is driven mainly by the slow mineralization of $\mathrm{S}$ rich plant biomass, recalcitrant to decomposition. Adsorption and desorption processes seem to play only a negligible role on our investigated stands. We conclude that our proposed model which is based on the current understanding of S biogeochemistry is sufficient to describe $\mathrm{S}$ dynamics on the investigated forest stands. The code file (SAS) for all model functions will be provided by the authors after request.
\end{abstract}

Keywords Sulfur deposition · Occult deposition · Sulfur biogeochemistry $\cdot \mathrm{SO}_{4}$ soil solution $\cdot$ Nutrient balance model . Simulated annealing

\section{Introduction}

During the Twentieth century, Central European forest ecosystems received high loads of atmospheric S. Several reasons led to a sharp decrease in $\mathrm{S}$ emissions and accordingly deposition, starting in the late 1980s. From 1990 to 2016, sulfur emissions could be reduced by $81 \%$ in Austria (Umweltbundesamt 2018). This decrease was assignable to policy-driven shifts in the energy sector, mainly the reduction in the use of S-rich fossil fuel, coupled with the installation of end-of-pipe technology. With declining emission, also the deposition load to forest ecosystems decreased. In the period from 1984 to 2013 throughfall (plus stemflow) fluxes for an Austrian beech stand sank

Torsten W. Berger

torstern.berger@boku.ac.at

1 Department of Forest- and Soil Sciences, Institute of Forest Ecology, University of Natural Resources and Life Sciences (BOKU), Peter Jordan-Straße 82, 1190 Vienna, Austria from 2.3 to $0.6 \mathrm{~g} \mathrm{~m}^{-2}$ year $^{-1}$ (Berger and Muras 2016). However, the observed drop was only poorly reflected in the catchment output of most forest sites (Alewell 2001; Alewell et al. 2001; Pannatier et al. 2011; Prechtel et al. 2001). Similar patterns were also reported from Northern America: The observed decline of acid deposition was, in most cases, not accompanied with a decline of acidifying agents in the stream output of the investigated catchments (Watmough et al. 2005). This was in strong contrast to the prediction of, at that time, state-of-the-art ecosystem simulators, which forecasted a relatively fast response of solution and stream chemistry after a change in the deposition regime. Likens et al. (2002) postulated 4 mechanisms, explaining a negative input/output balance of $S$ : (1) the release of $S$ by bedrock weathering, (2) a net release from the ion adsorber, (3) the excess mineralization of historically accumulated organic S or (4) the underestimation of dry $\mathrm{S}$ deposition. Studies of the isotopic composition of the atmospheric $S$ input and the catchment $S$ output clearly pointed toward an organic source (Novák et al. 
2000). Especially for catchments which received high historic loads of anthropogenic $\mathrm{S}$, the isotopic composition of the stream discharge showed higher portions of ${ }^{32} \mathrm{~S}$ than the atmospheric input. Plants and soil microflora generally prefer the lighter ${ }^{32} \mathrm{~S}$ isotope toward the heavier, less abundant ${ }^{34}$ S (Mitchell et al. 2001; Zhang et al. 1998). Sulfur, which was biologically incorporated into organic material during phases of high deposition, was now being released steadily, in form of $\mathrm{SO}_{4}-\mathrm{S}$ by mineralization. Novák et al. (2000) state that a considerable amount of the atmospherically deposed $\mathrm{S}$ is cycled through the biosphere before being given off to the soil solution and the stream discharge. Ecosystem models such as MAGIC, SMART, SAFE or CHESS describe S storage and release based solely on sorption isotherms (compare Alewell 2001). They share their neglect in the possibility of biotic S cycling and the storage of S incorporated in an organic pool. In an attempt to model the stream chemistry of the output of a forested catchment in Germany with the MAGIC model, it was necessary to introduce an additional S source ( $968 \mathrm{mg} \mathrm{m}^{-2} \mathrm{yr}^{-1}$ ) to match the simulated with the observed stream discharge (Prechtel et al. 2003). Gbondo-Tugbawa et al. (2001) found that the introduction of a plant $\mathrm{S}$ uptake and a mineralization module considerably increased the performance of the PnET-BGC model in describing the $\mathrm{SO}_{4}-\mathrm{S}$ output of a forested catchment.

In this work, we introduce a novel biogeochemical model to describe $\mathrm{S}$ dynamics of temperate deciduous forest stands. Besides the assessment of geochemical dynamics, we lay emphasis on biotic interactions: In addition to plant uptake, litterfall and the release of $\mathrm{S}$ via mineralization of plant organic material, we try to assess microbial immobilization (the microbial conversion of soil solution sulfate to organically bond $\mathrm{S}$ ) in the forest soil as a crucial part of the biogeochemical $\mathrm{S}$ cycle. The model is applied to two beech stands in eastern Austria where deposition and solution chemistry were monitored closely over a two-year period. In this work, we try to answer the following questions:

- Is it possible to derive a model configuration that delivers a plausible representation of the current state of the investigated sites and of the observed temporal pattern in the soil solution?

- Does this model configuration provide insight, which biogeochemical processes are the key drivers of the observed intra-annual pattern in the $\mathrm{SO}_{4}$-S soil solution?

- Furthermore, is the simulator, which is calibrated on data from a very narrow timeframe, capable to provide a reasonable perspective regarding the future development of the stands' $\mathrm{S}$ budget and balance? How long does it take for the stream discharge of $\mathrm{S}$ to decline to a pre-industrial level? Is a new steady state (balance between $\mathrm{S}$ input and $\mathrm{S}$ output) foreseeable within the model timeframe?

\section{Materials and methods}

\section{Study sites}

The investigated forest stands are located in the northeasterly part of Austria at the eastern edge of the Vienna Woods (see Fig. 1). The parent material for soil formation is Flysch, which consists of old tertiary and mesozoic sandstones and clayey marls of maritime origin. Due to a high clay content, the saturated hydraulic conductivity is low, leading to frequent episodes of waterlogging. Therefore, the soil type is classified as Stagnic Cambisol according to the WRB soil classification (IUSS Working Group 2006), throughout both studied sites. The mean annual temperature in the study area is approximately $9{ }^{\circ} \mathrm{C}$. The average annual precipitation is $660 \mathrm{~mm}$ (Wien-Hohe Warte).

The first site Exelberg (E) is located in Lower Austria close to the border to Vienna ( $\left.48^{\circ} 14^{\prime} 40^{\prime \prime} \mathrm{N}, 16^{\circ} 15^{\prime} 18^{\prime \prime} \mathrm{E}\right)$, at an elevation of $460 \mathrm{~m}$ a. s. 1 . This site is a pure beech stand. We estimated its age to approximately 100 years. The stand is facing SE with an inclination of $22 \%$. The second site Jubiläumswarte (J) is located within the municipal area of Vienna at the eastern edge of the Vienna Woods $\left(48^{\circ} 13^{\prime} 12^{\prime \prime} \mathrm{N}, 16^{\circ} 15^{\prime} 56^{\prime \prime} \mathrm{E}\right), 2.8 \mathrm{~km}$ southeast of E, at an elevation of $440 \mathrm{~m}$ a. s. 1. The site, which is also a pure beech stand with an estimated age of 125-150 years, is also facing SE, with an inclination of $15 \%$. As a matured stand, it is showing signs of collapse but also strong natural regeneration. In contrast to the $\mathrm{E}$ stand, the bedrock of the $\mathrm{J}$ site contains calcareous material, reflected in higher base saturation and soil $\mathrm{pH}$. Both forest stands are located at upper hill slopes, close to the hilltop. Due to their southeasterly exposition they are very susceptible to direct air flow, coming from the urban area of Vienna. Further details about forest site, stand and soil characteristics are given in Hanousek et al. (2017).

\section{Data sources}

The simulator, which we outline in this work, runs on a daily timestep. Therefore, all input data must be provided in daily resolution. Sulfur enters and leaves the soil system mainly in aqueous solute form. To describe the short-term dynamics of $\mathrm{S}$ in the soil, we simulate water balance and water fluxes, using the formulation of the Water Balance Model (WBM) presented in the supplementary of Dolschak et al. (2019). We ran the WBM using meteorological input data from the weather station Jubiläumswarte $(100 \mathrm{~m}$ distant from $\mathrm{J}$ ) obtained from the Zentralantalt für Meteorologie und Geodynamik (ZAMG). The meteorological 


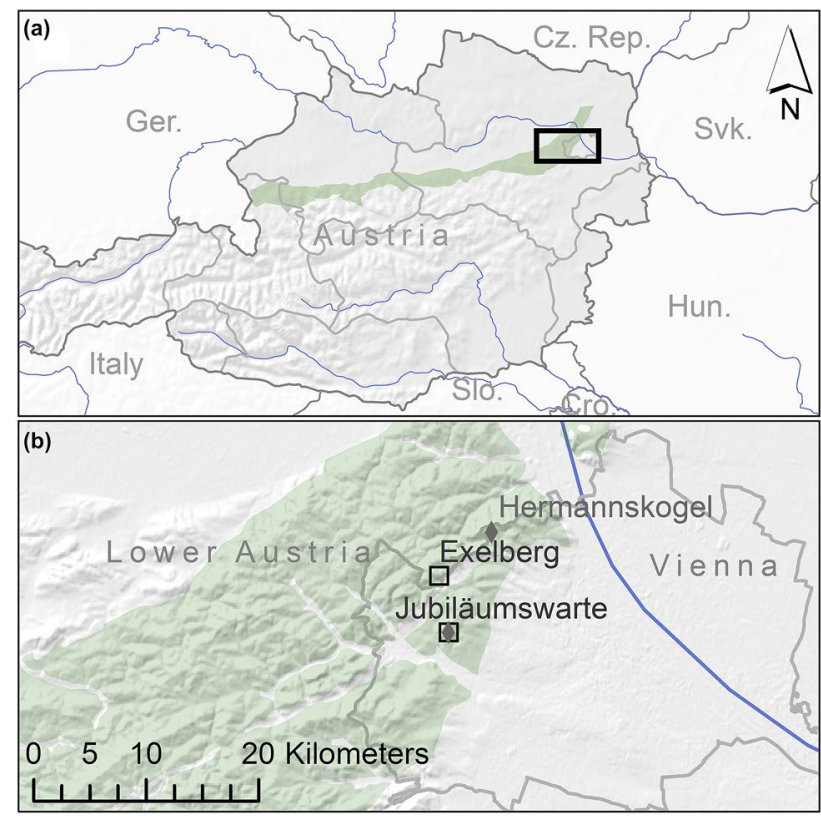

Fig. 1 a Location of the investigated sites in Lower Austria and Vienna. Both sites share the bedrock Flysch (darker band area, crossing Northern Austria) and several other site characteristics. b Both forest stands (squares) are located at upper hill slopes, close to the ridge, facing SE. Due to the sites' microrelief, in combination with the immediate proximity to the urban area of Vienna, they are deemed very susceptible for pollution-enriched air flow from south to easterly directions. Weather information and $\mathrm{SO}_{2}$ data (diamonds) were obtained mainly from Jubiläumswarte and Hermannskogel

record of the mentioned station starts in 2011. For the timeframe before that year, we created a synthetic weather time series using neighboring stations with longer records; outside the timeframe with measured data, we applied a weather generator to create a synthetic record. We used the daily mean air temperature and snapshot measurements of soil temperature to generate a continuous record of soil temperature. The approach plus its parameterization is described in Dolschak et al. (2015). To determine the timing of the stands' phenological key events, we used the phenological module, which is also presented in Dolschak et al. (2019).

Both investigated sites were monitored from April 2010 to June 2012 in a biweekly interval. Precipitation water was collected in the open field (bulk precipitation), as well as after the passage through the canopy (throughfall). A funneling apparatus was installed on one tree per site to collect stemflow. Soil solution lysimeters were installed at 10, 30 and $50 \mathrm{~cm}$ soil depth, each in 5 replications per site. Snapshot measurements of soil moisture (TDR-Trase) and soil temperature were taken in the course of the biweekly sample collection. Water samples (precipitation and soil solution) were analyzed for $\mathrm{SO}_{4}$-S content via ion chromatography (Dionex DX 500, USA).

Daily mean values of the aerial $\mathrm{SO}_{2}$ concentration were obtained from the Umweltbundesamt (Wiener Umweltschutzabteilung-MA 22 Luftmessnetz), for the site Hermannskogel, ranging back to the year 1988. To extrapolate these data to the pre-industrial era, we used a time series of the estimated $\mathrm{SO}_{4}$-S deposition, derived by Schöpp et al. (2003). This time series was normalized to a value of one for the period with existing data (compare Fig. 2b). Outside the timeframe, we multiplied the normalized estimate with the Day of Year (DoY) mean from the measured period. The data estimates range back to 1880 . The dataset also comprises estimates for the near future. For our purposes, we chose the CLE (Current Legislation Emission) scenario. Outside the defined timeframe, we extended the time series, assuming static conditions before the first and after the last year of prognosis.

On both sites, bulk precipitation deposition of $\mathrm{SO}_{4}$-S (open field) was sampled from April 2010 to June 2012 in a biweekly interval. To achieve a daily resolution, we prorated the collected amount proportionally to the measured amount of daily precipitation. For the extension of deposition to the time period before measured data were available, we used a similar approach as with the $\mathrm{SO}_{2}$ air concentration (Fig. 2c).

\section{Model description}

Disregarding S inputs from dry deposition and gaseous losses, $\mathrm{S}$ enters and leaves the undisturbed forest ecosystem mainly in aqueous solute form $\mathrm{SO}_{4}{ }^{2-}$ (Likens et al. 2002). Consequently, there is a strong link between biogeochemical $\mathrm{S}$ balance and the hydrologic balance. Also the $\mathrm{S}$ uptake by plants, the mineralization of S-containing biomass (Moyano et al. 2012; Sierra et al. 2015) as well as other microbially mediated $\mathrm{S}$ transformations in the soil are assumed to show a strong response to soil moisture (Aulakh et al. 2002; Janzen and Bettany 1987; Solberg et al. 2005). Therefore, an expedient description of the water balance seems crucial for modeling the $\mathrm{S}$ dynamics of a forest stand.

The simulator, which we outline in this article, works as an extension to the WBM; running the Sulfur Dynamics Model (SDM) requires the output of the WBM. Additional to that, the simulator requires daily information about $\mathrm{SO}_{4}-\mathrm{S}$ inputs via wet deposition above the canopy. To calculate the amount of dry and occult deposition, the daily mean $\mathrm{SO}_{2}$ air concentration is required. For the calculation of biological $\mathrm{S}$ transformations in the soil, the mean daily soil temperature of the soil is required. All other required input data are derived from the output of the WBM simulation. Fluxes, associated with the solute phase of S (canopy interception, snow dynamics, infiltration, bypass flow, percolation), are fully controlled by the associated water fluxes, defined 


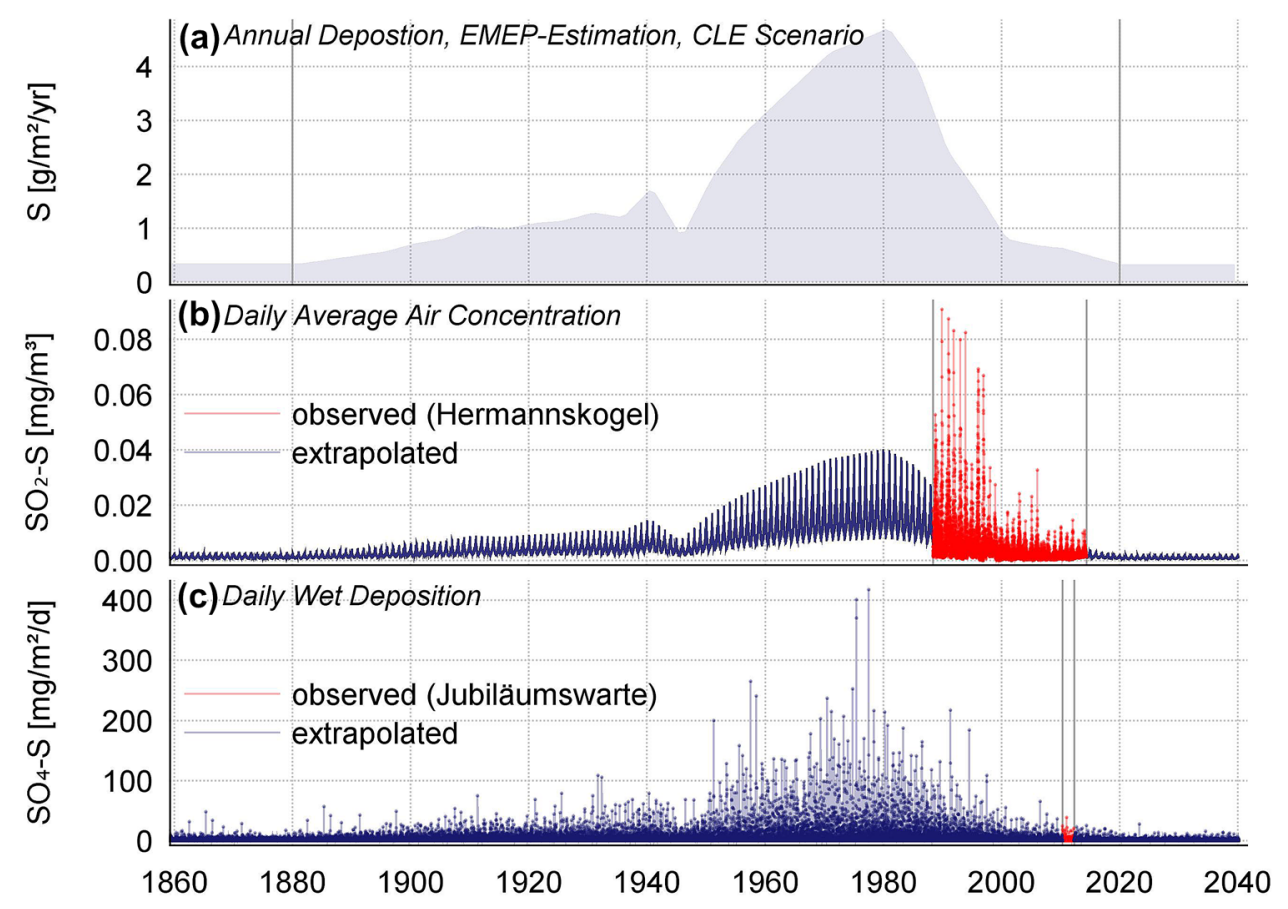

Fig. 2 Extrapolation of observed deposition data to the model timeframe. The model timeframe spans from 1770 to 2100 . Observations of $\mathrm{S}$ deposition and air concentration were available only for the very recent past. a To extend our input data time series beyond the observed time frames we used a dataset of $\mathrm{SO}_{4}-\mathrm{S}$ deposition estimates (EMEP), generated by Schöpp et al. (2003). The data estimates range back to 1880 . The set also comprises estimates for the near future. For our purposes, we chose the Current Legislation Emission (CLE) scenario. Outside the defined timeframe, we extended the time series, assuming steady conditions. b Daily mean values of the

through the WBM. All these processes are calculated, using the following scheme. The change in the content of the solute $\left(\mathrm{mg} / \mathrm{m}^{2}\right)$ of the desired pool is defined as the product of content and the relative change of the water content of the pool during the timestep.

$\frac{d \operatorname{Cont}}{d t}=\operatorname{Cont} \frac{\frac{d \text { Water }}{d t}}{\text { Water }}$

Analog to the WBM, the SDM can be divided into an aboveground and a belowground module. A flowchart of both formulations is given in Fig. 3. Only two aboveground processes are explicitly modeled in the SDM: occult (fog) deposition and dry (stomatal) deposition. We assume the $\mathrm{SO}_{4}$-S concentration in fog precipitation proportional to the $\mathrm{SO}_{2}$ concentration in the air. The amount of daily fog deposition $\left(\mathrm{mg} / \mathrm{m}^{2}\right)$ is calculated as the product of fog precipitation $(\mathrm{mm})$, the average daily $\mathrm{SO}_{2}-\mathrm{S}$ air concentration $\left(\mathrm{mg} / \mathrm{m}^{3}\right)$, multiplied with a specific enrichment factor.

occult $=\mathrm{SO}_{2} \mathrm{Sf}_{\text {occult }} \mathrm{FOG}$ aerial $\mathrm{SO}_{2}$ concentration for the site Hermannskogel, were available, ranging back to the year 1988 . Due to the fact that $\mathrm{SO}_{2}$ concentrations exhibit a strong seasonal pattern, extrapolation was performed by calculating average values on a Day of Year base, which were then extended beyond the available timeframe. Here, the normalized EMEP time series served as a multiplier to scale the aerial concentration to historic/future conditions. c For daily wet deposition, we applied an approach, similar to the extension of the aerial concentration. Annual deposition sums where partitioned proportionally to daily precipitation events

The determination of stomatal deposition also utilizes data of the $\mathrm{SO}_{2}-\mathrm{S}$ air concentration. As proxy for the degree of stomatal openness we use the soil moisture-dependent stress coefficient $\left(K c_{\mathrm{s}, \text { tree }}\right)$ (compare Dolschak et al. 2019). A value of one would correspond to fully opened stomata, whereas a value of zero would result in a complete shutdown of the stomatal gas exchange. The stands' relative leaf area $\left(K c_{\text {LAI }}\right)$ serves as proxy for the foliage surface (or the relative amount of stomata), exposed to sulfur dioxide. The function is stated as a product of the $\mathrm{SO}_{2}-\mathrm{S}$ air concentration $\left(\mathrm{mg} / \mathrm{m}^{3}\right)$, a specific enrichment factor, the stress coefficient, the relative leaf area and the daily mean wind speed $(\mathrm{m} / \mathrm{s})$, measured $2 \mathrm{~m}$ above ground.

$d r y=\mathrm{SO}_{2} S f_{\text {dry }} K c_{s, \text { tree }} K c_{\text {LAI }} u_{2}$

Belowground and biotic S fluxes and transformations are stated as a system of five ordinary differential equations which are solved simultaneously using the 4th-order explicit Runge-Kutta scheme. The temporal dynamics of $\mathrm{SO}_{4}-\mathrm{S}(\mathrm{Sol})$ in the soil solution are formulated, using the following equation. Infiltration (Inf) and the leaching (Leac) of 


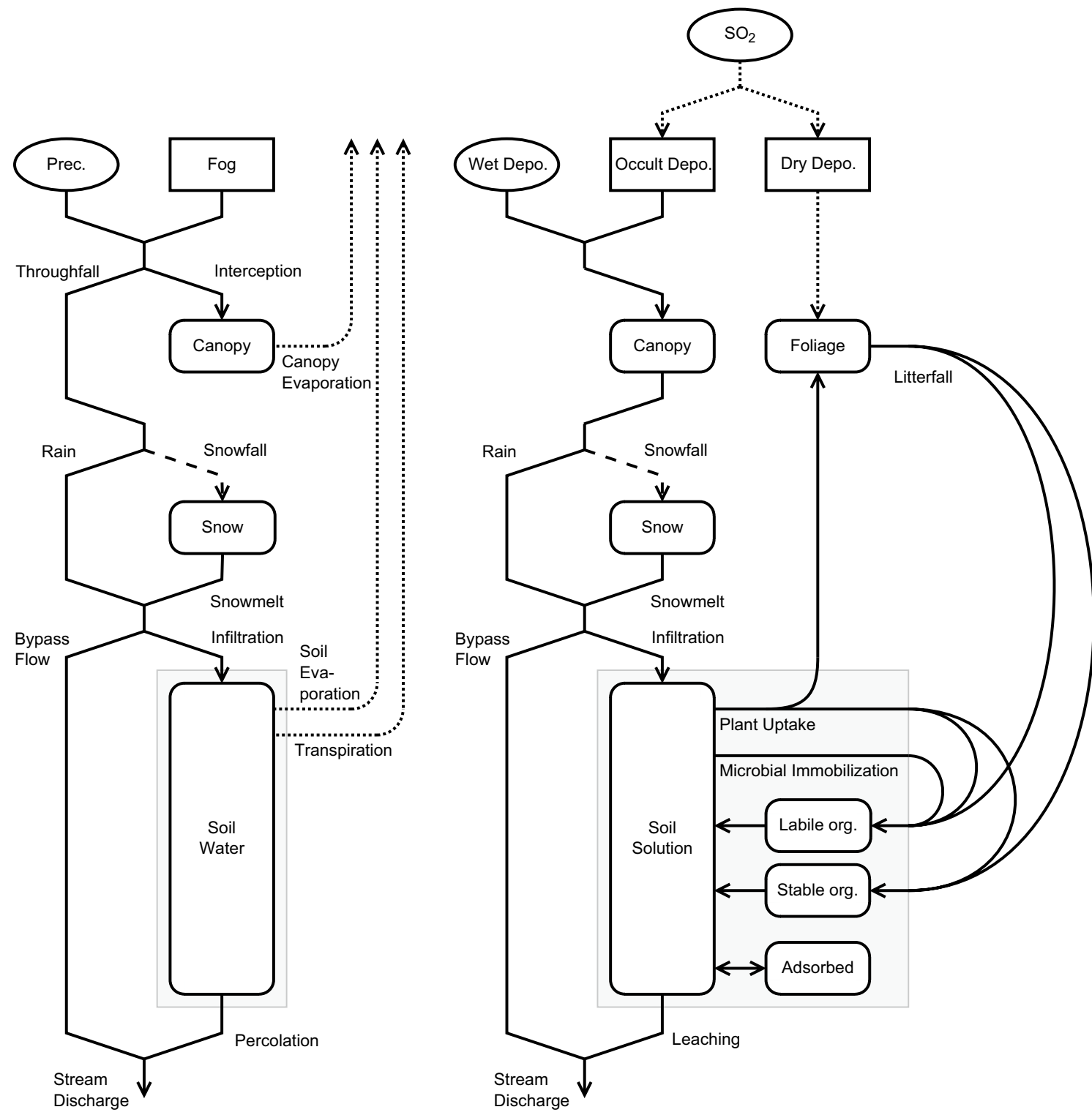

Fig. 3 Flowchart of the Water Balance Model (WBM, left) and the Sulfur Dynamics Model (SDM, right). A comprehensive description of the WBM is given in Dolschak et al. (2019). The WBM states the hydrologic framework for the SDM. All S fluxes, associated with the solute phase, are controlled by the WBM

Foliage $\mathrm{S}(\mathrm{Fol})$ dynamics are described as the difference of plant uptake, multiplied with a constant fraction, describing the partition of plant uptake, routed to the foliage, plus dry deposition input to the canopy, minus the autumnal litterfall loss of S. The simulator neglects the possibility of $\mathrm{S}$ washout from the canopy. The seasonal foliage $\mathrm{S}$ pool is the only explicitly defined biomass pool in the SDM. As our interest does not lie in tree growth, we do not assume a change in S storage during stand development. It could be 
claimed that living biomass $\mathrm{S}$ storage is incorporated in the labile as well as the stabile soil organic S pool.

$\frac{d F o l}{d t}=f_{\text {fol }} U_{\text {plant }}+d r y-$ litter

In our model, two pools are used to describe the dynamics of organic soil sulfur: A stable pool accounts for recalcitrant organosulfur compounds, and a labile pool accounts for more transitory organic sulfur species. The first pool could be viewed as corresponding to carbon-bond S, and the second could be assigned to ester-bond sulfate (McGill and Cole 1981). As a simplification, we assume that microbial S immobilization is only contributing to the labile pool. The balance of the labile organosulfur pool can be stated as the difference of the labile partition of plant uptake, which is not routed to the foliage, and litterfall, plus the microbial $\mathrm{S}$ assimilation, and the loss via mineralization. As a simplification, we assume a steady-state forest with an unchanging $\mathrm{S}$ content in the living woody biomass.

$\frac{d \text { Labile }}{d t}=f_{\text {labile }}\left(\left(1-f_{\text {fol }}\right) U_{\text {plant }}+\right.$ litter $)+U_{\text {micro }}-M_{\text {labile }}$

The stable pool is formulated analog to the labile pool. The stabile fraction of plant uptake and litterfall is formulated as $1-f_{\text {labile. }}$.

$\frac{d \text { Stable }}{d t}=\left(1-f_{\text {labile }}\right)\left(\left(1-f_{\text {fol }}\right) U_{\text {plant }}+\right.$ litter $)-M_{\text {stable }}$

Sulfate adsorption is modeled using the Langmuir isotherm. $M_{\text {ads }}$ and $K_{\text {ads }}$ are site-specific model parameters, and Conc states the $\mathrm{SO}_{4}-\mathrm{S}$ concentration in the soil solution. To express the kinetics of the process, it is coupled with a first-order decay function.

$\frac{d A d s}{d t}=\lambda_{\mathrm{ads}}\left(\frac{M_{\mathrm{ads}} K_{\mathrm{ads}} \operatorname{Conc}[m g / L]}{1+K_{\mathrm{ads}} \operatorname{Conc}[m g / L]}-A d s\right)$

The concentration of $\mathrm{SO}_{4}-\mathrm{S}$ in the soil solution is calculated as the storage in soil solution, divided by the product of soil depth and soil moisture.

$\operatorname{Conc}[m g / L]=\frac{\operatorname{Sol}\left[m g / m^{2}\right]}{z_{\mathrm{r}} \theta}$

We derive the lambda value from the process' half-life.

$\lambda_{\mathrm{ads}}=-\frac{\ln 0.5}{H L_{\mathrm{ads}}}$

The function stated below describes the response $\left(\operatorname{resp}_{\mathrm{Q} 10}\right)$ of microbial $\mathrm{S}$ transformations to soil temperature. We use a base temperature of $8^{\circ} \mathrm{C}$ that should resemble the annual average soil temperature at our investigated stands. The factor $f_{\mathrm{Q} 10}$ describes the relative increase in the response when soil temperature rises by $10^{\circ} \mathrm{C}$.

$r e s p_{\mathrm{Q} 10}=e^{\frac{\ln f_{\mathrm{Q} 10}}{10}\left(T_{\mathrm{soil}}-8^{\circ} \mathrm{C}\right)}$

In the WBM, the autumnal decrease in the LAI inside the interval $D o Y_{\text {LC }}-D o Y_{\text {LE }}$ (compare Dolschak et al. 2019) is described using the Smoothstep function (see Appendix). To define the relative amount of sulfur in the litterfall (litter) we first calculate the relative amount of daily litterfall $\left(f_{\text {litter }}\right)$.

$f_{\text {litter }}= \begin{cases}0, & D o Y<D o Y_{\mathrm{LC}} \\ 1-\frac{L A I_{\mathrm{Kc}, \mathrm{DoY}}}{L A I_{\mathrm{Kc}, \mathrm{DoY}-1}}, & D o Y_{\mathrm{LC}} \leq D o Y<D o Y_{\mathrm{LE}} \\ 1, & D o Y=D o Y_{\mathrm{LE}}\end{cases}$

To calculate the amount of sulfur in the litterfall biomass we multiply this value with the sulfur content in the foliage pool.

litter $=f_{\text {litter }}$ fol

The latter function describes the response $\left(\operatorname{resp}_{\theta}\right)$ of microbial $\mathrm{S}$ transformations to soil moisture (see Sverdrup et al. 2007). At soil moisture levels below $\left(\theta_{0}\right)$ and above a certain threshold $\left(\theta_{3}\right)$, we claim that all microbial transformations come to a halt ( resp $_{\mathrm{opt}}=0$ ). We assume optimal conditions ( $r e s p_{\text {opt }}$ ) at medium soil moisture between $\theta_{1}$ and $\theta_{2}$. In between $\theta_{0}$ and $\theta_{1}$ and accordingly in between $\theta_{\text {moist }}$ and $\theta_{\text {drown }}$ we assume linear transitions.

$r e s p_{\theta}=r e s p_{\min }+\left(r e s p_{\mathrm{opt}}-r e s p_{\min }\right) \begin{cases}0, & \theta \leq \theta_{0} \vee \theta<\theta_{3} \\ \frac{\theta-T_{0}}{T_{1}-T_{0}}, & \theta_{0}<\theta \leq \theta_{1} \\ 1, & \theta_{1}<\theta \leq \theta_{2} \\ 1-\frac{\theta-T_{2}}{T_{3}-T_{2}}, & \theta_{2}<\theta \leq \theta_{3}\end{cases}$

$V_{m}=\frac{V_{\max } \operatorname{Conc}[m g / L]}{K_{\mathrm{m}}+\operatorname{Conc}[m g / L]}$

We describe microbial $S$ immobilization using the Michaelis-Menten equation.

$V_{\mathrm{m}, \text { immobil }}=\frac{V_{\mathrm{max}, \text { immobil }} \operatorname{Conc}[m g / L]}{K_{\mathrm{m}, \text { immobil }}+\operatorname{Conc}[m g / \mathrm{L}]}$

The maximal assimilation rate depends on soil temperature and soil moisture.

$V_{\text {max,immobil }}=V_{\text {coeff,immobil }} r e s p_{\mathrm{Q} 10, \text { immobil }} r e s p_{\theta, \text { immobil }}$

We describe the mineralization of stable organic $\mathrm{S}$ as first-order decay process, dependent on soil temperature and soil moisture. 
$M_{\text {stable }}=$ Stable $\lambda_{\text {stable }} r e s p_{\mathrm{Q} 10, \text { mineral }} r e s p_{\theta, \text { mineral }}$

The release of labile organic $\mathrm{S}$ (ester-bond) is also described as first-order decay process dependent on soil temperature and soil moisture. In addition, the rate of mineralization is also dependent on the $\mathrm{SO}_{4}-\mathrm{S}$ soil solution concentration.

$M_{\text {labile }}=$ Labile $_{\text {sulfatase }} r e s p_{\mathrm{Q} 10, \text { mineral }} r e s p_{\theta \text {,mineral }}$

The simulator comprises the effect of microbial sulfatase release on the kinetics of the labile organic $\mathrm{S}$. A low $\mathrm{SO}_{4}$ concentration in the soil solution promotes the microbial release of sulfatase, thus accelerating the mineralization release of ester-bond sulfate (Scherer 2009). This is implemented by making the process' half-life linearly dependent on the soil solution concentration. To set the linear dependence, half-lives are defined for 2 key solution concentrations (0 and $10 \mathrm{mg} \mathrm{SO}_{4}-\mathrm{S} / \mathrm{L}$ ).

$k_{\text {sulfatase }}=\frac{H L_{\text {sulfatase. } 10}-H L_{\text {sulfatase. } 0}}{10}$

The linear equation takes the form:

$H L_{\text {sulfatase }}=k_{\text {sulfatase }} C[m g / L]+H L_{\text {sulfatase. } 0}$

The half-life is used to calculate the lambda value of the first-order decay process.

$\lambda_{\text {sulfatase }}=-\frac{\ln 0.5}{H L_{\text {sulfatase }}}$

The $\mathrm{S}$ uptake of deciduous trees is mediated through two distinct active carrier systems (Herschbach and Rennenberg 2001). Kreuzwieser and Rennenberg (1998) postulate high affinity and low affinity uptake systems. Low sulfate level in the aqueous phase of forest soils points to the dominance of the high affinity system (Herschbach and Rennenberg 2001). We simulate the uptake of $\mathrm{S}$ beech trees using Michaelis-Menten kinetics. We assume that plant uptake is only taking place during the growing season.

$U_{\text {plant }}= \begin{cases}\frac{V_{\text {maX, }, \text { plant }} \operatorname{Conc}[\mathrm{mg} / \mathrm{L}]}{K_{\mathrm{m}, \text { plant }}+\operatorname{Conc}[\mathrm{mg} / \mathrm{L}]}, & K c_{\mathrm{LAI}}>0 \\ 0, & K c_{\mathrm{LAI}}=0\end{cases}$

We also claim that plants only take up a certain amount of $\mathrm{S}$ during the season. After a certain demand is met $\left(A C U_{\text {starve }}\right)$, plants start to throttle the uptake. After a second threshold is met $\left(A C U_{\text {sat }}\right)$, plants shut down the uptake of $\mathrm{S}$ completely. We calculate the accumulated uptake on a Day of Year base.

$A C U_{\text {DoY }}=\left\{\begin{array}{lr}0, & D o Y=1 \\ U_{\text {plant }}+A C C_{\text {DoY }-1}, & D o Y>1\end{array}\right.$
The transition of the demand is modeled under the usage of the Smoothstep function (see Appendix).

$V_{\text {max,plant }}=\operatorname{smooth}\left(A C U_{\text {DoY }}\left[g / m^{2}\right], A C U_{\text {starve }}, A C U_{\text {sat }}, V_{\text {starve,plant }}, V_{\text {sat,plant }}\right)$

\section{Model application}

Before running the SDM, we define three target criteria, which mark a successful simulation:

- To bootstrap the SDM, we run a model spin-up, starting in the year 1770 . As a primary requisite, the model must achieve steady-state conditions before atmospheric deposition starts to rise in 1880 .

- The plots were sampled and analyzed in 2010, and the total $\mathrm{S}$ stock in forest floor and mineral soil $(0-50 \mathrm{~cm})$ was determined (E: $78.0 \mathrm{~g} / \mathrm{m}^{2}, \mathrm{~J}: 102.6 \mathrm{~g} / \mathrm{m}^{2}$ ). The sum of all modeled soil $\mathrm{S}$ pools (adsorbed, stable organic, labile organic, soil solution) in 2010 has to be in a close range to the measured value.

- The simulator has to deliver a satisfactory reproduction of the observed timeline of the $\mathrm{SO}_{4}-\mathrm{S}$ concentration in the monitored soil solution.

We define plausible ranges for our set of 25 parameters (Table 1). The SDM was calibrated via simulated annealing (Kirkpatrick 1984). Performance criterion was the Nash-Sutcliffe model efficiency (NSE; Nash and Sutcliffe 1970), a function, which is generally used to evaluate hydrologic models.

The code file of the model (written in Base SAS 9.4) is available after request to the authors. The file contains the code for all model functions which are utilized in the Water Balance Model (WBM) and the Sulfur Dynamics Model (SDM). The recommended citation is: this publication: code file of the Water Balance Model (WBM) and the Sulfur Dynamics Model (SDM).

\section{Results and discussion}

\section{Evaluation}

Soil solution chemistry was monitored in a biweekly interval, on each site in 15 replications (Fig. 4a, b). This enables the calculation of robust site wise mean $\mathrm{SO}_{4}-\mathrm{S}$ soil solution concentrations per sampled event. The resulting timelines of both forest stands reveal a very similar pattern (Fig. 4c). The observed correlation gives a hint that sulfate solution chemistry might be driven by the same processes, on both stands.

Regarding the timeline of $\mathrm{SO}_{4}-\mathrm{S}$ in soil solution, the SDM yields feasible results for both investigated stands: 
The simulations capture the observed timeline to a satisfactory degree (Exelberg: $N S E=0.78$, Jubiläumswarte: $N S E=0.9$, compare Fig. 5f, g, Table 1). The SDM overestimates the amount of total soil-S, which was quantified in 2010. For the $\mathrm{E}$ and $\mathrm{J}$ plot, the observed mean of the total soil-S pool down to a depth of $50 \mathrm{~cm}$ was $78.0 \mathrm{~g} / \mathrm{m}^{2}$ and $102.6 \mathrm{~g} / \mathrm{m}^{2}$ (Hanousek et al. 2017). The SDM delivers an estimate of 103 and $128 \mathrm{~g} / \mathrm{m}^{2}$ (see Fig. 6c, d). Therefore, it overestimates both sites' pools, each by approximately $25 \mathrm{~g} / \mathrm{m}^{2}$. Given the fact that the presented model does not explicitly account for organic S, bond in living tree biomass other than foliage, one could argue that a portion of the modeled organic pool is contained in the aboveground plant tissue. For a beech-rich northern hardwood forest (Hubbard Brook Experimental Forest), Likens et al. (2002) give an estimate for the S, bound in aboveground living biomass, of $8.5 \mathrm{~g} / \mathrm{m}^{2}$ roughly. Subtracting $1.0 \mathrm{e} \mathrm{g}$ representing foliage $S$ this narrows the gap, reducing the overestimation to approximately $17.5 \mathrm{~g} / \mathrm{m}^{2}$.

Soil samples from both investigated sites were analyzed for $\mathrm{S}$ fractions by Hanousek et al. (2017). Additionally, they used material from a third site to create pooled samples. Adsorbed S was determined to a fraction of $6.4 \%$ of total soil S. The organic fraction accounted for $89 \%$. Our modeling work delivers similar values. On both locations, adsorbed and organic fraction account for roughly $6.0 \%$ and $93.5 \%$ (Fig. 6c, d).

The organic fraction can further be divided into carbon-bonded $\mathrm{S}$ and ester-sulfates. For a nearby beech stand on similar bedrock the ester fraction was determined by Hanousek et al. (2017) via HI reduction (described in Kulhánek et al. 2011; Tabatabai 1996). The authors found that ester-sulfates account for approximately $38 \%$ of the entire organic fraction, which is in contradiction to Havlin et al.
Table 1 Parameter optimization results for the investigated sites

\begin{tabular}{|c|c|c|c|c|}
\hline Abbrev. & Parameter and description & Unit & Exelberg & Jubiläum. \\
\hline$f_{\text {occult }}$ & Fog (occult deposition) enrichment factor & & 33922.35 & 15395.36 \\
\hline$f_{\text {dry }}$ & Stomatal (dry) deposition factor & & 0.00 & 0.00 \\
\hline$\Theta_{0, \text { mineral }}$ & Mineralization, lower threshold $\Theta$ & $\mathrm{LL}^{-1}$ & 0.07 & 0.01 \\
\hline$\Theta_{1, \text { mineral }}$ & Mineralization, lower optimal $\Theta$ & $\mathrm{LL}^{-1}$ & 0.13 & 0.25 \\
\hline$\Theta_{2 \text {,mineral }}$ & Mineralization, upper optimal $\Theta$ & $\mathrm{LL}^{-1}$ & 0.23 & 0.33 \\
\hline$\Theta_{3, \text { mineral }}$ & Mineralization, upper threshold $\Theta$ & $\mathrm{LL}^{-1}$ & 0.36 & 0.39 \\
\hline$\Theta_{0, \text { immobil }}$ & Immobilization, lower threshold $\Theta$ & $\mathrm{LL}^{-1}$ & 0.04 & 0.04 \\
\hline$\Theta_{1, \text { immobil }}$ & Immobilization, lower optimal $\Theta$ & $\mathrm{LL}^{-1}$ & 0.07 & 0.18 \\
\hline$\Theta_{2, \text { immobil }}$ & Immobilization, upper optimal $\Theta$ & $\mathrm{LL}^{-1}$ & 0.16 & 0.29 \\
\hline$\Theta_{3, \text { immobil }}$ & Immobilization, upper threshold $\Theta$ & $\mathrm{LL}^{-1}$ & 0.33 & 0.38 \\
\hline$H L_{\text {stable }}$ & Half-life, stable soil-organosulfur, opt. Conditions & Years & 54.71 & 67.34 \\
\hline$H L_{\text {labile }}$ & Half-Life, Labile Soil-Organosulfur, opt. conditions & Days & 21.99 & 13.00 \\
\hline$K_{\mathrm{m}, \text { immobil }}$ & Immobilization, $K_{\mathrm{m}}$ parameter & & 1.81 & 1.05 \\
\hline$V_{\mathrm{m}, \text { immobil }}$ & Immobilization, maximum rate, opt. conditions & $\mathrm{SO}_{4}-\mathrm{S} \mathrm{mg} \mathrm{m}^{-2}$ & 2.11 & 2.11 \\
\hline$f_{\mathrm{Q} 10, \text { immobil }}$ & Immobilization, Q10 Factor & & 2.37 & 2.77 \\
\hline$f_{\mathrm{Q} 10, \text { mineral }}$ & Mineralization, Q10 Factor & & 2.19 & 2.22 \\
\hline$V_{\mathrm{m}, \mathrm{starve}}$ & Plant Uptake, Maximum Rate at S Starvation & $\mathrm{SO}_{4}-\mathrm{S} \mathrm{mg} \mathrm{m}^{-2} \mathrm{~d}^{-1}$ & 0.11 & 0.07 \\
\hline$V_{\mathrm{m}, \mathrm{sat}}$ & Plant Uptake, Maximum Rate at S Saturation & $\mathrm{SO}_{4}-\mathrm{S} \mathrm{mg} \mathrm{m}^{-2} \mathrm{~d}^{-1}$ & 0.00 & 0.00 \\
\hline$K_{\text {m,plant }}$ & Plant uptake, $K \mathrm{~m}$ parameter & & 1.16 & 0.95 \\
\hline $\mathrm{TC}_{\text {starve }}$ & Plant uptake, threshold uptake, starvation & $\mathrm{SO}_{4}-\mathrm{S} \mathrm{mg} \mathrm{m}{ }^{-2} \mathrm{y}^{-1}$ & 1141.79 & 913.76 \\
\hline$T C_{\text {sat }}$ & Plant uptake, threshold uptake, saturation & $\mathrm{SO}_{4}-\mathrm{S} \mathrm{mg} \mathrm{m}^{-2} \mathrm{y}^{-1}$ & 1367.79 & 2166.95 \\
\hline$f_{\text {labile }}$ & Plant uptake, routed to labile soil-organosulfur & & 0.18 & 0.07 \\
\hline$f_{\text {fol }}$ & Plant uptake, routed to foliage pool & & 0.74 & 0.82 \\
\hline$H L_{\text {ads }}$ & Adsorption, half-life & Days & 205.00 & 71.10 \\
\hline$K_{\mathrm{L}, \mathrm{ads}}$ & Adsorption, half-saturation concentration & $\mathrm{SO}_{4}-\mathrm{S} \mathrm{mg} \mathrm{L}^{-1}$ & 12.53 & 11.68 \\
\hline \multirow[t]{5}{*}{$K_{\text {max,ads }}$} & Adsorption, maximum charge & $\mathrm{SO}_{4}-\mathrm{S} \mathrm{mg} \mathrm{m}^{-2}$ & 6085.48 & 7057.02 \\
\hline & Initialization 1770 , labile soil-organosulfur & $\mathrm{SO}_{4}-\mathrm{S} \mathrm{mg} \mathrm{m}^{-2}$ & 5054.55 & 6804.58 \\
\hline & Initialization 1770 , stable soil-organosulfur & $\mathrm{SO}_{4}-\mathrm{S} \mathrm{mg} \mathrm{m}^{-2}$ & 51175.13 & 61845.05 \\
\hline & Plant uptake 2010 & $\mathrm{SO}_{4}-\mathrm{S} \mathrm{mg} \mathrm{m}^{-2}$ & 1345.80 & 1245.00 \\
\hline & Litterfall 2010 & $\mathrm{SO}_{4}-\mathrm{S} \mathrm{mg} \mathrm{m}^{-2}$ & 992.40 & 1017.40 \\
\hline$N S E$ & Nash-sutcliffe index & & 0.78 & 0.90 \\
\hline$R M S E$ & Root-Mean-Square Error & & 0.44 & 0.28 \\
\hline
\end{tabular}


Fig. 4 a, b Time series of $\mathrm{SO}_{4}-\mathrm{S}$ concentration, observed in soil solution. Each line represents one lysimeter. Eighteen lysimeters were installed per plot 6 repetitions and 3 depth classes). c To overcome the noise in the data, the SDM was fitted to site-wise mean concentrations. After calculating the mean, both sites reveal a very similar pattern regarding the temporal development of the soil solution concentration. This is leading to the assumption that soil S dynamics are controlled by over-regional drivers

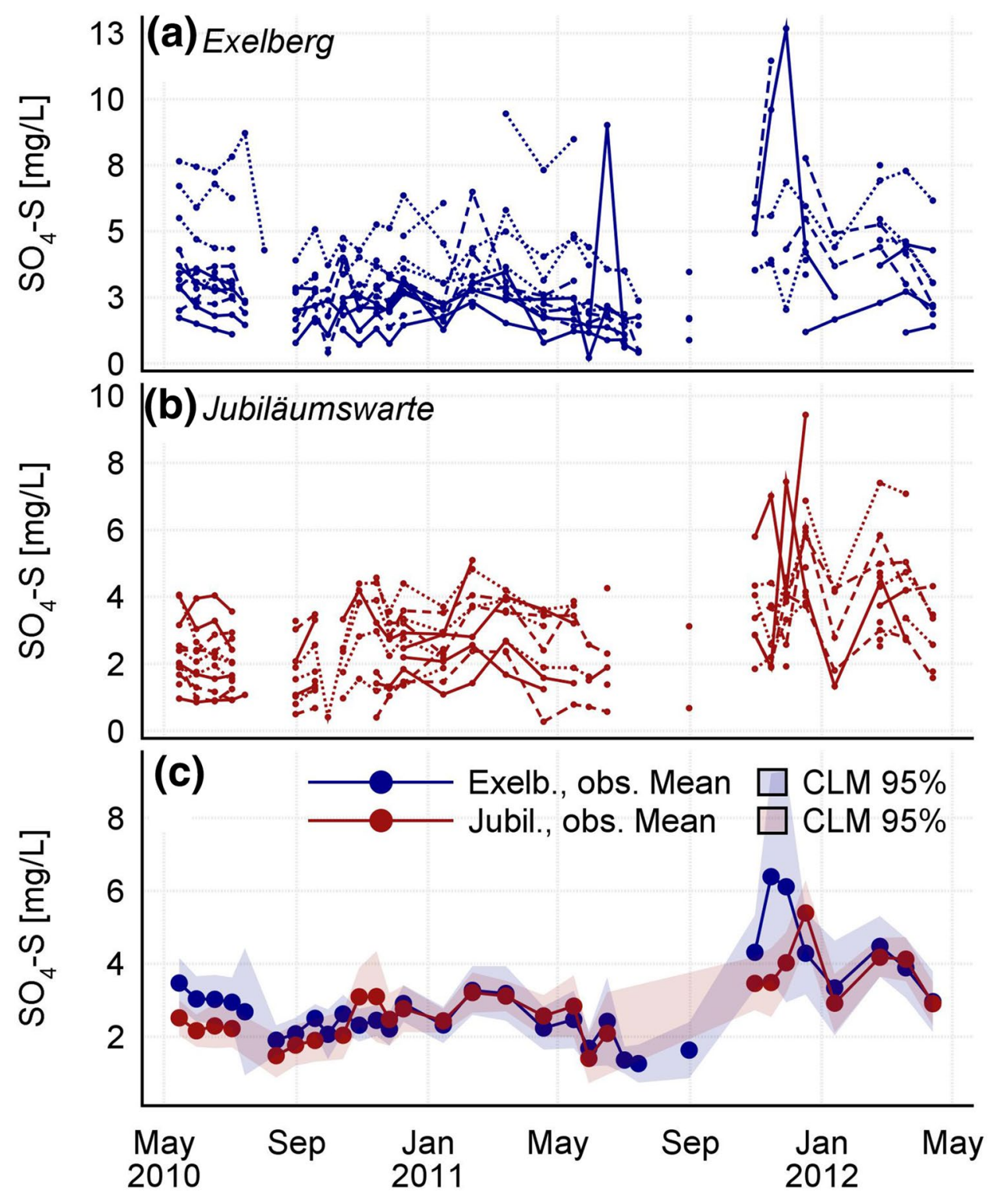

(2005) who suggest that ester-sulfates account for the majority of organic soil S. Our hypothesis that labile soil organosulfur corresponds to ester-sulfates must be rejected: Accounting for only $3.5 \%$ (E) and $4.5 \%$ (J) or organic soil S, our simulated labile pool (June 2010) is even smaller than reported by Hanousek et al. (2017).

For a beech stand on similar bedrock, Berger et al. (2009) reported an annual litterfall $\mathrm{S}$ flux of $0.45 \mathrm{~g} / \mathrm{m}^{2}$. However, the $\mathrm{S}$ content in green foliage tissue was more than two times higher than in litter material, indicating translocation processes before leaf senescence. Our simulations exhibit values, of $1.0 \mathrm{~g} / \mathrm{m}^{2}$ per year. This overestimation could be explained by the neglect of plant-internal $\mathrm{S}$ translocations in the current version of the SDM.

\section{Microbial S transformations}

Compared to other soil $\mathrm{S}$ pools, the microbial $\mathrm{S}$ pool is small. According to Chowdhury et al. (1999), microbially bond $\mathrm{S}$ accounts only for $1-4 \%$ of total soil $\mathrm{S}$. Nevertheless, it is of great importance regarding plant nutrition due to its labile nature. Kertesz and Mirleau (2004) describe the contribution of microbial activity to the plant $\mathrm{S}$ supply: Plants take up $\mathrm{S}$ primarily in form of inorganic $\mathrm{SO}_{4}$ (Buchner et al. 2004). However, only a minor fraction of soil $\mathrm{S}$ is available in this form. As stated before, the majority is contained in organic material. Soil microbiota are responsible for the mineralization of organically bond $\mathrm{S}$ to inorganic sulfate. On the other hand, microorganisms are also driving the rapid immobilization of inorganic sulfate, first to relatively labile ester sulfates and furthermore, to more stable C-bonded S 


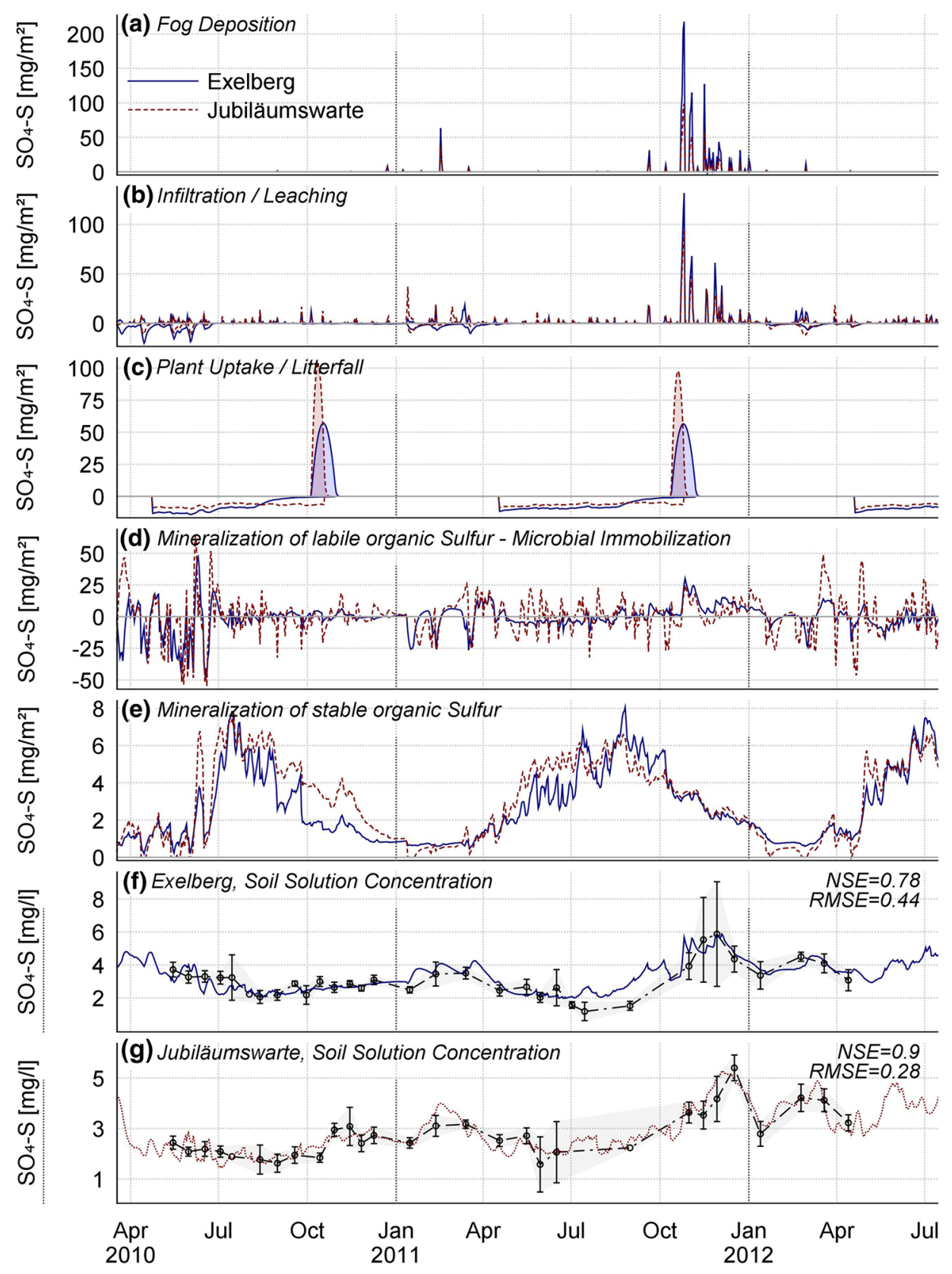

Fig. $5 \mathrm{~S}$ fluxes during two years of field campaign. a Both stands experience a prolonged fog event in the autumn of 2011. During this period, we measured occult deposition loads between 200 and $500 \mathrm{mg} \mathrm{SO}-\mathrm{S} / \mathrm{m}^{2}$. The simulation outcome suggests much higher values: From mid-October to the end of December 2011, the simulator predicts occult deposition sums of 1800 and $900 \mathrm{mg} \mathrm{SO} \mathrm{S}_{4} \mathrm{~S} / \mathrm{m}^{2}$, for the Exelberg and Jubiläumswarte site, respectively. b During the field campaign, atmospheric inputs were dominated by the occult deposition event in the fall of 2011. Due to the coupling with percolation, leaching of $\mathrm{SO}_{4}$-S only takes place, when soil moisture is above water-holding capacity. This happens predominantly during the dormant season when evapotranspiration water fluxes are low. c We model plant uptake taking place only during the growing season. Because plant uptake is driven by their demand in our simulation, highest rates of $\mathrm{S}$ assimilation are achieved relatively early in the growing season. As the annual demand is met in late summer, plants start to throttle the uptake of S. During autumnal litter- fall, the $\mathrm{S}$, which is stored in leaf biomass, is transferred to the soil organic pool. d In this graph, we display the difference of mineralization of labile organosulfur and microbial immobilization. Positive values represent inputs to the soil solution meaning that mineralization is dominating. The erratic pattern is caused by shifted $\Theta$ optima for both processes (comp. Figs. 7, 8). Mineralization slightly favors higher $\Theta$ values than immobilization. e Mineralization is driven by substrate availability, $\Theta$, and soil temperature. Maximal values are achieved at moderate $\Theta$ and high soil temperature (comp. Figs. 7, 8). f, $g$ Observed and modeled timeline of the $\mathrm{SO}_{4}$-S concentration in the soil solution. The dash-dotted line illustrates the stands mean concentration at given time, and the error bars display the $95 \%$ confidence limit for the mean. The calibration led to sufficiently good results for both investigated forest stands. Both sites exhibit a peak in the solution concentration in late autumn of 2011. This is assignable to (1) high input loads via fog deposition and (2) mineralization excess during this period 
species (Ghani et al. 1993). In our formulation, $S$ taken up by plants is routed to both stabile and labile organosulfur. In contrast to plant uptake, microbial immobilization contributes only to the labile pool. We describe mineralization and immobilization of the labile organic pool as temperature and moisture dependent. The soil moisture optima are slightly displaced (see Fig. 7): Immobilization is favored by dryer soil conditions. Immobilization also exhibits stronger response to warm conditions (compare Fig. 8). Kertesz and Mirleau (2004) see immobilization and mineralization as concurrent processes, occurring simultaneously in the soil. In our simulations, it is in fact the non-congruence of soil moisture and temperature response, which is driving a large portion of the observed fluctuations in the $\mathrm{SO}_{4}$ soil solution, favoring net mineralization under cool and moist conditions and net immobilization under warm and slightly dryer conditions.

\section{Occult deposition}

During two years of field campaign, we captured a prolonged fog event in late autumn of 2011. There is a solid body of work, asserting that fog water is enriched in sulfate, compared to rainwater (see Fowler et al. 1989; Lange et al. 2003). Especially in mountainous regions, fog can contribute significantly to the hydrologic and nutrient balance (Klemm and Wrzesinsky, 2007). We monitored deposition (1) in the open and (2) below the canopy (throughfall) and in form of (3) stemflow. The accumulated S deposition sums clearly display significant $\mathrm{S}$ inputs via occult deposition during the captured fog event (compare Fig. 9). The observed discrepancy between open area deposition and throughfall plus stemflow deposition indicates an extra input of approximately $500 \mathrm{mg} \mathrm{SO}_{4}-\mathrm{S} \mathrm{m}^{-2}$. For our modeling purposes, we deal with open area deposition as input. The derivation of fog precipitation is presented in Dolschak et al. (2019).To scale from the mean daily aerial $\mathrm{SO}_{2}-\mathrm{S}$ concentration to the $\mathrm{SO}_{4}$-S concentration in the fog precipitation water, we apply an enrichment factor (see Lange et al. 2003). From 22nd October to 5th December 2011, the simulation yields an input of 1330 and $620 \mathrm{mg} \mathrm{SO}_{4}-\mathrm{S} \mathrm{m}^{-2}$ in form of occult deposition for $\mathrm{E}$ and $\mathrm{J}$. The spike in the soil solution at the end of 2011 (see Fig. 5a, f, g) is mostly assignable to fog deposition inputs. The observed and predicted high loads might be a result of the stands' local conditions: In the Vienna Basin, winter fog events often coincide with southeasterly currents. When passing over the urban area, the air becomes enriched with pollutants. At the edge of the Vienna Woods it is forced to rise, condensation starts. The forest stands, which are located at the upper hill slope, facing south to east, are acting as a first barrier for the enriched fog, making them susceptible for the interception of high loads of atmospheric S. For a detailed description see Auer et al. (1989).

\section{Historic development and future prospect}

Both stands display a strong rise in the total soil S pool during the Twentieth century (compare Fig. 6a, b). This can be assigned largely to the accumulation of stable organosulfur originating from plant residuals. Interestingly, the accumulation of stable $\mathrm{S}$ has not fully tapered off in the present decade. In an attempt, to predict the future $S$ output of two German catchments with the MAGIC model (Cosby et al. 2001). Prechtel et al. (2003) found that for one catchment the observed $\mathrm{SO}_{4}$ release could not be explained solely by adsorption/desorption processes in the soil. It was necessary to introduce an additional S source $\left(968 \mathrm{mg} \mathrm{m}^{-2} \mathrm{yr}^{-1}\right)$ to match the simulated with the observed stream output. The authors suggested an $\mathrm{S}$ release from decomposition of organic soil constituents. In our work, S from mineralization of stable organosulfur adds a relatively steady annual amount between 700 and $1300 \mathrm{mg}(1980-2020)$ to the budget. However, in our simulations, only a limited fraction of mineralized $\mathrm{S}$ enters the stream output. As the availability of other $\mathrm{S}$ sources might dwindle in the future, this fraction could further decrease. Much rather than being exported, it might be rapidly incorporated into living biomass and be cycled through the biosphere again. On the other hand, the remaining fraction which is leaving the system via seepage might hinder the achievement of a balanced input/output for many decades. Prechtel et al. (2003) point out that the investigated catchments could reach pre-industrial conditions in a few decades. They also claim that knowledge of origin and behavior of the postulated organic sulfur is crucial for the prediction of future trend in the stream chemistry. In our work, a large organic S pool with modeled half-lives up to 67 years will allow only a slow temporal recession of the catchment $\mathrm{S}$ export over the coming decades (see Fig. 10): Pre-industrial conditions in the stream discharge as well as a steady-state equilibrium are not reached over the whole investigation timeframe. The modeled amount of $\mathrm{SO}_{4}$-S, adsorbed in the soil, exhibits low variability over time. Simulated sorption is close to the modeled maximum sorption capacity on both sites $\left(K_{\text {max,ads }}=6.1 \mathrm{~g} \mathrm{SO}_{4}-\mathrm{S} \mathrm{m}^{-2}\right.$ Exelberg, $7.1 \mathrm{~g} \mathrm{SO} 4-\mathrm{S} \mathrm{m}^{-2}$ Jubiläumswarte). On both sites, these pools remain almost constant over the entire model timeframe (see Fig. 6a, b) and therefore does not contribute to the present output excess of $\mathrm{S}$.

Mineralization of S-containing soil constituents shows a strong response to soil moisture and soil temperature. Mitchell and Likens (2011) state the importance of the water balance in controlling the $\mathrm{S}$ output of forested watersheds: Soil moisture affects the net stream discharge, mineralization, desorption and weathering of S-bearing minerals. High temperatures might also accelerate processes. On the other hand, due to increase in evapotranspiration, high temperatures might lead to dryer soil conditions (see also Dolschak 

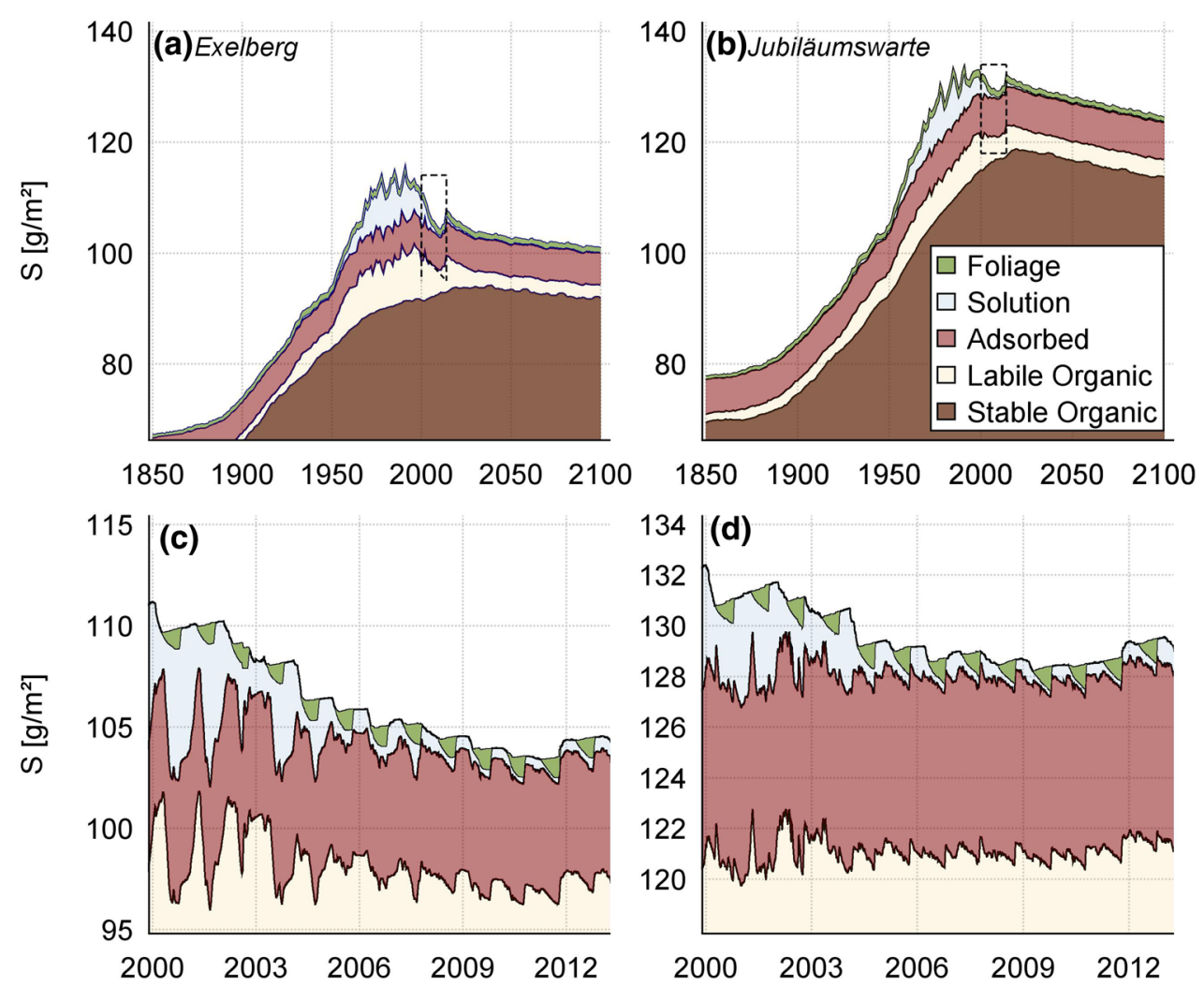

Fig. 6 Temporal development of S pools over the whole model timeframe $(a, b)$ and focused on the recent past $(c, d)$. a, b The model displays a rise in the stands' overall S stock, which is mainly assignable to the stable organosulfur pool (dark brown). Interestingly, this increase still has not tapered in the present decade. From the 1960s to the late 1980s S deposition peaked; high S loads are reflected in altered labile organosulfur and solute $\mathrm{SO}_{4}-\mathrm{S}$ in the soil. The amount of $\mathrm{SO}_{4}-\mathrm{S}$, adsorbed in the soil, shows the lowest variability. Simulated sorption (E: $6.0 \mathrm{~g}, \mathrm{~J} 6.8 \mathrm{~g}$ ) is during most periods close to the modeled maximum sorption capacity on both sites $\left(K_{\text {max,ads }}=6.1 \mathrm{~g}\right.$ $\mathrm{SO}_{4}-\mathrm{S} \mathrm{m}^{-2}$ Exelberg, $7.1 \mathrm{~g}$ SO4-S m${ }^{-2}$ Jubiläumswarte). We estimated both stands' total soil S pool in 2010. On the Exelberg site, an estimated amount of $78 \mathrm{~g} / \mathrm{m}^{2}$ corresponds to a simulated soil S pool of $103 \mathrm{~g} / \mathrm{m}^{2}$. The Jubiläumswarte soil S pool was estimated to $102 \mathrm{~g} /$

et al. 2019) impeding release and the export of S. Hence, how a changing climate might affect the stands' $\mathrm{S}$ dynamics has yet to be explored.

\section{Inactive modules}

\section{Stomatal deposition}

We assume that plants take up S primarily over the roots. Additionally, it is possible that airborne $\mathrm{SO}_{2}$ contributes to plant nutrition via the stomatal pathway (Rennenberg et al. 1990). We model stomatal deposition as a function of aerial $\mathrm{SO}_{2}$ concentration, the relative leaf area, the stomatal degree of openness (see Dolschak et al. 2019) and the wind speed. The calibration process always leads to stomatal deposition $\mathrm{m}^{2}$ in June 2010 and $128 \mathrm{~g} / \mathrm{m}^{2}$ was simulated. Both sites exhibit two peaks of the total S pool: one at the end of the 1980s and one at the end of the monitoring period. The second peak might be caused by a high recurrence of deposition-rich fog events in this period. After 2020 both sites display a slow recession of $\mathrm{S}$ pools which does not reach steady state until the end of the prediction timeframe in 2100 . c, $\mathbf{d}$ The model does not explicitly account for $\mathrm{S}$, stored in non-green living plant biomass. The $\mathrm{S}$ uptake fraction, which is not assigned to foliage $S$, is routed to the soil organic S pool, where it is instantaneously exposed to mineralization. The simulated $\mathrm{S}$ content of foliage lies in the range of $1 \mathrm{~g} / \mathrm{m}^{2}$. S is modeled, to be taken up steadily during the growing season. Autumnal litterfall leads to a sharp increase in the soil organic $\mathrm{S}$ pools

rates close to zero. It seems possible that (1), under current atmospheric $\mathrm{SO}_{2}$ concentration, stomatal uptake plays only a negligible role in plant nutrition or (2) the effect of stomatal uptake is comprised in other simulated modules.

\section{Soil sulfatase activity}

The SDM comprises the effect of microbial sulfatase release on the kinetics of the labile organic $\mathrm{S}$. Deficits in the $\mathrm{S}$ supply (low $\mathrm{SO}_{4}$-S solution concentration) promote the microbial release of sulfatase, thus accelerating the mineralization of organically bond sulfate (Scherer 2009). We implement this by introducing half-lives of the labile organic pool, linearly dependent on the soil solution concentration. Yet during model fitting, concentration-dependent half-lives did not improve the 

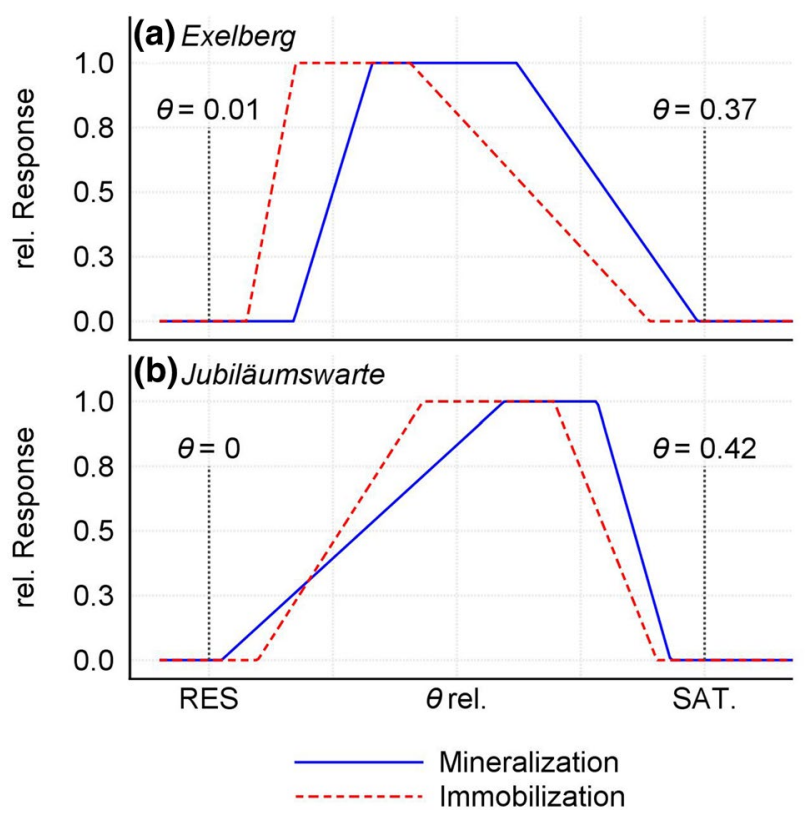

Fig. 7 Response of microbial $\mathrm{S}$ transformations to soil moisture $(\Theta) . \Theta$ is displayed on a relative scale, whereas 0 corresponds to the residual water content and 1 to soil saturation, respectively. The response of microbial processes to $\Theta$ was described using a piecewise linear function. On both sites, the calibration led to mineralization and immobilization optima at medium $\Theta$ where a balanced water and oxygen supply are given. The range of maximal immobilization rates is slightly shifted to drier soil conditions (compare Table 1). In our model simulations, the non-congruence between the moisture response of immobilization and mineralization is responsible for short-term fluctuations in the $\mathrm{SO}_{4}$-S soil solution concentration

performance of the simulator. Comparable to stomatal deposition, it seems possible that (1) other modeled processes already cover the effect of microbial sulfatase release. It might also be thinkable that (2) the observed $\mathrm{SO}_{4}$ supply in the soil solution is sufficiently high to fully meet the needs of soil microflora. Hence, the release of exo-enzymes might be initiated at solution concentrations much lower than observed.

\section{Conclusion}

The objective of this work lies less in the long-term perspective of acidification recovery of forest soils; our primary interest lies in finding a mathematical description of the forest plant-soil system, capable to reproduce observed temporal patterns of the $\mathrm{SO}_{4}$-S in soil solution. Furthermore, we try to assign high-frequency fluctuations in the soil solution, observed on plot scale, to actual biogeochemical processes in the soil. After that, we venture a very cautious prognosis of the future development of the plant-soil system's $\mathrm{S}$ budget on the investigated forest stands.

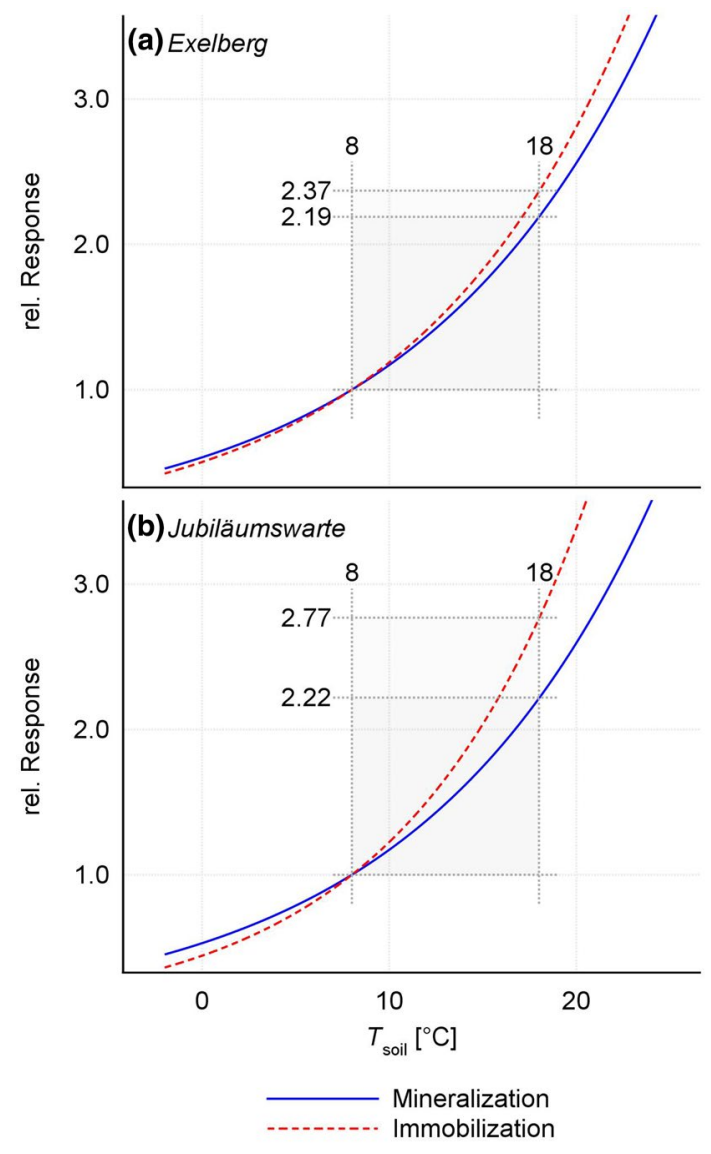

Fig. 8 Response of microbial $\mathrm{S}$ transformations to soil temperature. The effect of soil temperature was modeled, using the $Q_{10}$ temperature coefficient. We set the base temperature to $8{ }^{\circ} \mathrm{C}$, which is close to the annual mean soil temperature of the sites. The calibration process delivered similar $Q_{10}$ factors for both forest stands, whereas the temperature sensitivity of immobilization was slightly higher than the sensitivity for mineralization (compare Table 1)

We identify microbial $\mathrm{S}$ transformations as important driver of the short-term dynamics in the soil solution. Yet on the long run, the mineralization of plant-originated soil organic $S$ is responsible for the present input output imbalance. A large pool of historically accumulated organosulfur, which is decaying only very slowly, causes an output excess for decades or even centuries. Pre-industrial conditions in the stream discharge are not reached over the entire model timeframe. Besides that, occult deposition still contributes considerably to the supply of S to the forest.

For each plot, we deliver one set of parameters, which yields the best calibration result. We are aware that many different parameter configurations might lead to similar or even better outcomes. Nevertheless, the fact that it is even possible to find an adequate parameter set for each forest plot indicates that the current knowledge about forest soil S dynamics might be sufficient to describe the stands' dynamics to 
Fig. 9 Accumulated $\mathrm{SO}_{4}-\mathrm{S}$ deposition on both investigated stands. During late autumn 2011 both sites experience a sharp increase in throughfall deposition. This period coincides with a long-lasting fog event; occult deposition seems to be an important sulfate source during such events

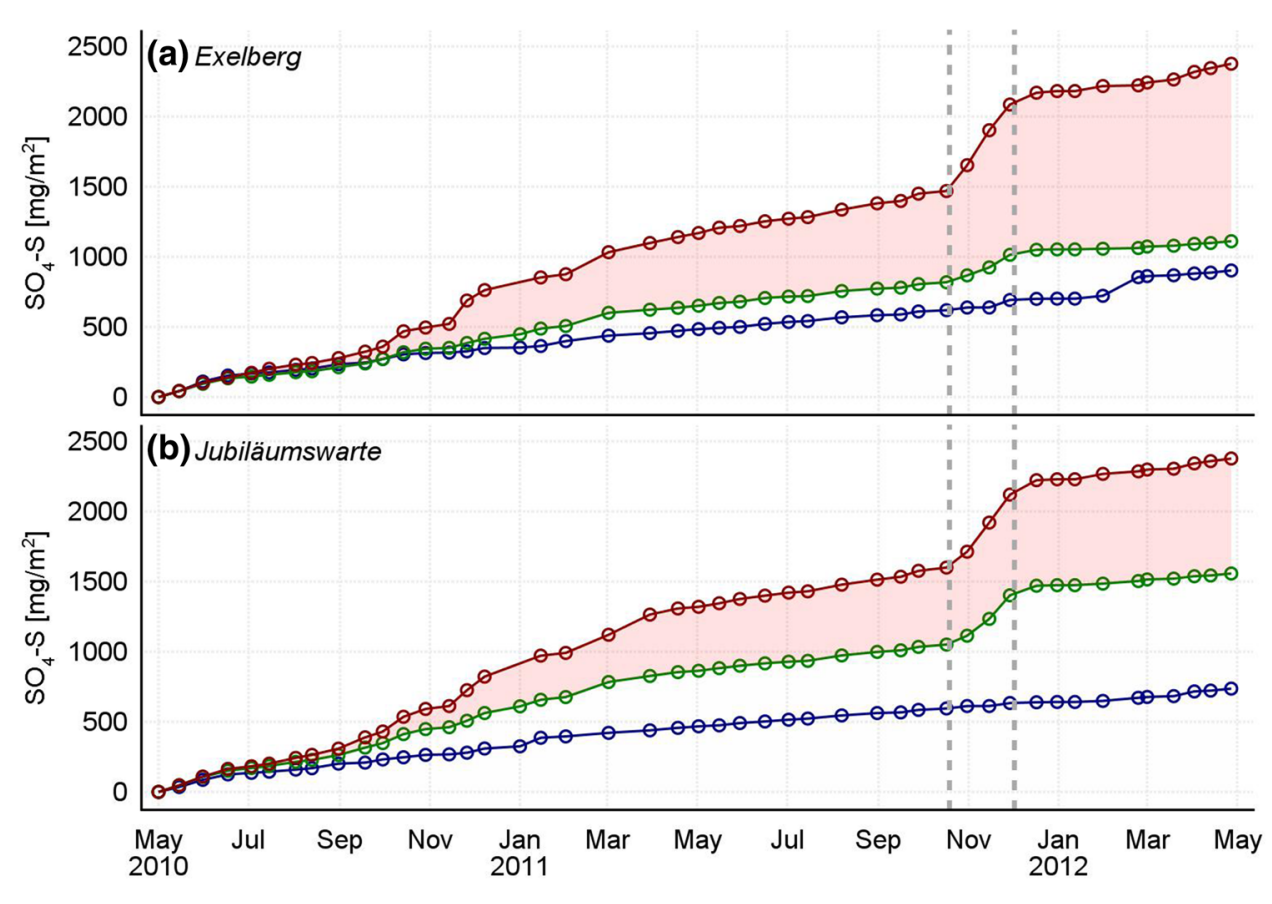

- Throughfall + Stemflow $\_$Throughfall $\_$Open Area Precipitation
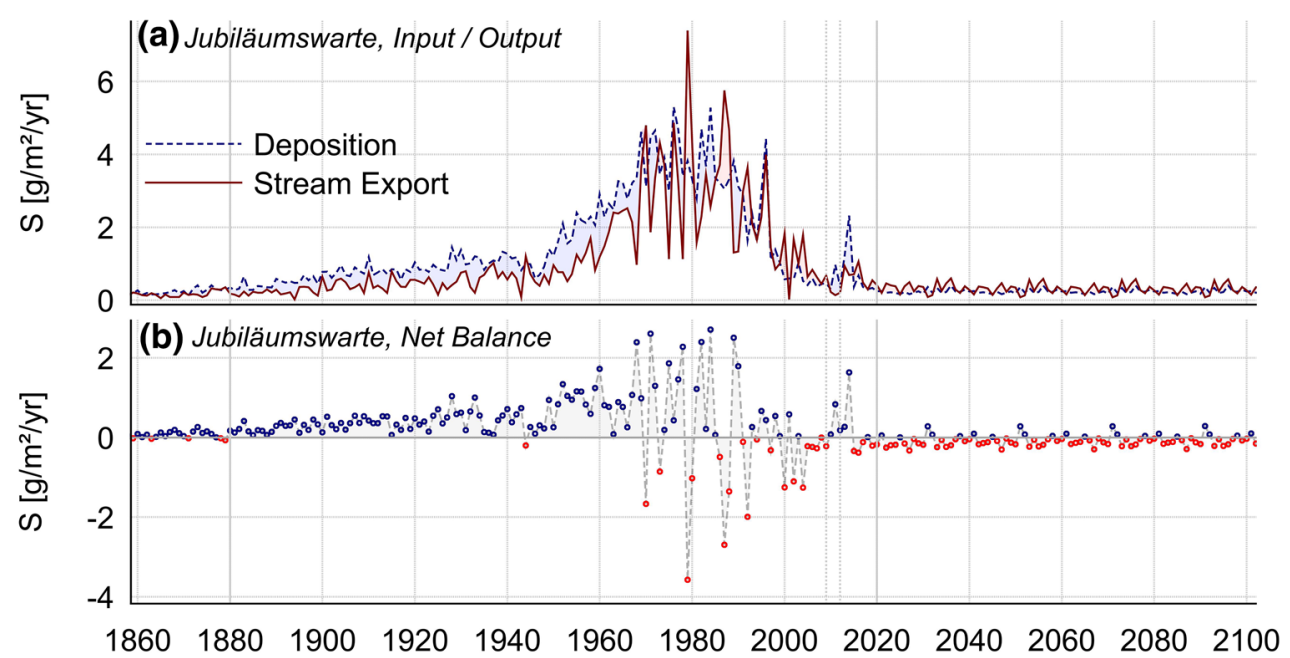

Fig. 10 Annual S input versus annual output (I/O) for the Jubiläumswarte site. After the spin-up period I/O is in steady state. With rising atmospheric deposition, the system shifts to input excess in the end of the Nineteenth century. Highest inputs are modeled around the year 1980. In the late 1980s, the system shifts to output domination for the first time. A second smaller peak of input excess around the year 2015 is caused by a frequent occurrence of fog events in this period.

a satisfactory degree. At least in the short period that was monitored no unexplainable artifacts remain, requiring fundamental reconsideration of the assumptions about the workings of soil $\mathrm{S}$ dynamics. At this point, it seems like we cover all essential processes, necessary to illustrate a comprehensive picture of the stands' current $\mathrm{S}$ cycling.
After 2020 the model predicts a steady recession of input and output with output moderately dominating inputs for the remaining time period. At the end of the investigation timeframe in the year 2100, the system has still not fully restored I/O equilibrium and stream discharge of $\mathrm{SO}_{4}-\mathrm{S}$ remains slightly above the level of the pre-industrial era, ending in 1880

\section{The code file of the model will be provided by the authors after request}

Filename: CODE_WBM_SDM.sas.

Title: Code file (Base SAS 9.4) for the WBM and the SDM. 
Description: The file contains the code for all model functions which are utilized in the Water Balance Model (WBM) and the Sulfur Dynamics Model (SDM).

Recommended citation: this publication: code file of the Water Balance Model (WBM) and the Sulfur Dynamics Model (SDM).

Acknowledgements This research was funded by the Austrian Science Fund (FWF, project number P23861-B16, granted to TW Berger) and the Commission for Interdisciplinary Ecological Studies (KIÖS) at the Austrian Academy of Sciences (Project Number 2010-05, granted to TW Berger). Open access funding was provided by the University of Natural Resources and Life Sciences Vienna (BOKU). For her active support during the field campaign, we thank Pétra Berger. For the possibility to access air temperature data, the providers in the ECA\&D project are acknowledged. We thank the ZAMG and the Austrian Hydrographic Service (eHYD) for the provision of meteorological data, which was used for gap filling purposes. For the provision of temperature and precipitation records, we thank the operator of a private weather station, Thomas Huber. We acknowledge the possibility to use records of $\mathrm{SO}_{2}$ provided online by the Umweltbundesamt. We thank Wolfgang Schöpp, Maximilian Posch, Sophia Mylona and Matti Johansson for the possibility to use estimates for historic $\mathrm{S}$ deposition for our desired EMEP grid cells (Schöpp et al. 2003). Finally, we thank for anonymous critical comments for the improvement of this paper.

Open Access This article is licensed under a Creative Commons Attribution 4.0 International License, which permits use, sharing, adaptation, distribution and reproduction in any medium or format, as long as you give appropriate credit to the original author(s) and the source, provide a link to the Creative Commons licence, and indicate if changes were made. The images or other third party material in this article are included in the article's Creative Commons licence, unless indicated otherwise in a credit line to the material. If material is not included in the article's Creative Commons licence and your intended use is not permitted by statutory regulation or exceeds the permitted use, you will need to obtain permission directly from the copyright holder. To view a copy of this licence, visit http://creativecommons.org/licenses/by/4.0/.

\section{Appendix}

To achieve sigmoid shape transitions of a variables $(x)$ response $(y)$ inside a window $\left(x_{0}-x_{1}\right)$, the Smoothstep function (compare Dolschak et al. 2015) was applied in several cases. $y_{0}$ and $y_{1}$ state left and right threshold responses, respectively. The variable $x$ has to be normalized into an auxiliary variable $(t)$ inside the interval $0-1$.

$t=\frac{x-x_{0}}{x_{1}-x_{0}}$

The transition is described using a third-order polynomial.

$y= \begin{cases}y_{0}, & x \leq x_{0} \\ y_{0}+\left(y_{1}-y_{0}\right)\left(3 t^{2}-2 t^{3}\right), & x_{0}<x<x_{1} \\ y_{1}, & x \geq x_{1}\end{cases}$

In the article, the Smoothstep function is stated as: $y=\operatorname{smooth}\left(x, x_{0}, x_{1}, y_{0}, y_{1}\right)$

\section{References}

Alewell C (2001) Predicting reversibility of acidification: the European sulfur story. Water Air Soil Pollut 130:1271-1276

Alewell C et al (2001) Are there signs of acidification reversal in freshwaters of the low mountain ranges in Germany? Hydrol Earth Syst Sci 5:367-378

Auer I, Böhm R, Mohnl H (1989) Klima von Wien: eine anwendungsorientierte Klimatographie. Beiträge zur Stadtforschung, Stadtentwicklung und Stadtgestaltung. Stadt Wien, Magistratsabteilung 18 - Stadtentwicklung und Stadtplanung, Vienna

Aulakh MS, Jaggi RC, Sharma R (2002) Mineralization-immobilization of soil organic $\mathrm{S}$ and oxidation of elemental $\mathrm{S}$ in subtropical soils under flooded and nonflooded conditions. Biol Fertil Soils 35:197-203

Berger TW, Muras A (2016) Predicting recovery from acid rain using the micro-spatial heterogeneity of soil columns downhill the infiltration zone of beech stemflow: introduction of a hypothesis. Model Earth Syst Environ 2(3):154

Berger TW, Untersteiner H, Toplitzer M, Neubauer C (2009) Nutrient fluxes in pure and mixed stands of spruce (Picea abies) and beech (Fagus sylvatica). Plant Soil 322:317-342

Buchner P, Takahashi H, Hawkesford MJ (2004) Plant sulphate transporters: co-ordination of uptake, intracellular and long-distance transport. J Exp Bot 55:1765-1773

Chowdhury MAH, Kouno K, Ando T (1999) Correlation among microbial biomass $\mathrm{S}$, soil properties, and other biomass nutrients. Soil Sci Plant Nutr 45:175-186

Cosby BJ, Ferrier RC, Jenkins A, Wright RF (2001) Modelling the effects of acid deposition: refinements, adjustments and inclusion of nitrogen dynamics in the MAGIC model. Hydrol Earth Syst Sci Dis 5:499-518

Dolschak K, Gartner K, Berger TW (2015) A new approach to predict soil temperature under vegetated surfaces. Model Earth Syst Environ 1(4):1-14

Dolschak K, Gartner K, Berger TW (2019) The impact of rising temperatures on water balance and phenology of European beech (Fagus sylvatica L.) stands. Model Earth Syst Environ 5(4):1-17

Fowler D, Cape JN, Unsworth MH (1989) Deposition of atmospheric pollutants on forests. Philos Trans R Soc Lond B Biol Sci 324(1223):247-265

Gbondo-Tugbawa SS, Driscoll CT, Aber JD, Likens GE (2001) Evaluation of an integrated biogeochemical model (PnET-BGC) at a northern hardwood forest ecosystem. Water Resour Res 37:1057-1070

Ghani A, McLaren RG, Swift RS (1993) The incorporation and transformations of $35 \mathrm{~S}$ in soil: effects of soil conditioning and glucose or sulphate additions. Soil Biol Biochem 25:327-335

Hanousek O, Prohaska T, Kulhanek M, Balik J, Tejnecky V, Berger TW (2017) Fractionation of sulfur (S) in beech (Fagus sylvatica) forest soils in relation to distance from the stem base as useful tool for modeling S biogeochemistry. Model Earth Syst Environ 3:1065-1079

Havlin JL, Beaton JD, Tisdale SL (2005) Soil fertility and fertilizers an introduction to nutrient management. Pearson, Prentice Hall, Upper Saddle River

Herschbach C, Rennenberg H (2001) Sulfur nutrition of deciduous trees. Naturwissenschaften 88(1):25-36

IUSS Working Group, W., 2006. World reference base for soil resources. World Soil Resources Report, 103 
Janzen HH, Bettany JR (1987) The effect of temperature and water potential on sulfur oxidation in soils. Soil Sci 144:81-89

Kertesz MA, Mirleau P (2004) The role of soil microbes in plant sulphur nutrition. J Exp Bot 55:1939-1945

Kirkpatrick S (1984) Optimization by simulated annealing-quantitative studies. J Stat Phys 34(5-6):975-986

Klemm O, Wrzesinsky T (2007) Fog deposition fluxes of water and ions to a mountainous site in Central Europe. Tellus Ser B Chem Phys Meteorol 59:705-714

Kreuzwieser J, Rennenberg H (1998) Sulphate uptake and xylem loading of mycorrhizal beech roots. New Phytol 140(2):319-329

Kulhánek M, Černý J, Balík J, Vaněk V, Sedlář O (2011) Influence of the nitrogen-sulfur fertilizing on the content of different sulfur fractions in soil. Plant Soil Environ 57(12):553-558

Lange CA, Matschullat J, Zimmermann F, Sterzik G, Wienhaus O (2003) Fog frequency and chemical composition of fog watera relevant contribution to atmospheric deposition in the eastern Erzgebirge, Germany. Atmos Environ 37(26):3731-3739

Likens GE et al (2002) The biogeochemistry of sulfur at Hubbard Brook. Biogeochemistry 60:235-316

McGill W, Cole C (1981) Comparative aspects of cycling of organic C, N, S and P through soil organic matter. Geoderma 26(4):267-286

Mitchell MJ, Likens GE (2011) Watershed sulfur biogeochemistry: shift from atmospheric deposition dominance to climatic regulation. Environ Sci Technol 45(12):5267-5271

Mitchell MJ et al (2001) Use of stable isotope ratios for evaluating sulfur sources and losses at the Hubbard Brook Experimental Forest. Water Air Soil Pollut 130(1-4):75-86

Moyano FE et al (2012) The moisture response of soil heterotrophic respiration: interaction with soil properties. Biogeosciences 9:1173-1182

Nash JE, Sutcliffe JV (1970) River flow forecasting through conceptual models part I - A discussion of principles. J Hydrol 10(3):282-290

Novák M et al (2000) Sulfur isotope dynamics in two Central European watersheds affected by high atmospheric deposition of SOx. Geochim Cosmochim Acta 64:367-383

Pannatier EG, Thimonier A, Schmitt M, Walthert L, Waldner P (2011) A decade of monitoring at Swiss Long-Term Forest Ecosystem Research (LWF) sites: can we observe trends in atmospheric acid deposition and in soil solution acidity? Environ Monit Assess 174:3-30

Prechtel A et al (2001) Response of sulphur dynamics in European catchments to decreasing sulphate deposition. Hydrol Earth Syst Sci 5:311-325
Prechtel A, Armbruster M, Matzner E (2003) Modelling sulphate stream concentrations in the Black Forest catchments Schluchsee and Villingen. Hydrol Earth Syst Sci Discuss Eur Geosci Union 7(4):552-560

Rennenberg H, Brunold C, De Kok L, Stulen I (1990) Sulfur nutrition and sulfur assimilation in higher plants. SPB Academic Publishing, The Hague

Scherer HW (2009) Sulfur in soils. J Plant Nutr Soil Sci 172:326-335

Schöpp W, Posch M, Mylona S, Johansson M (2003) Long-term development of acid deposition (1880-2030) in sensitive freshwater regions in Europe. Hydrol Earth Syst Sci Dis 7(4):436-446

Sierra CA, Trumbore SE, Davidson EA, Vicca S, Janssens I (2015) Sensitivity of decomposition rates of soil organic matter with respect to simultaneous changes in temperature and moisture. J Adv Model Earth Syst 7:335-356

Solberg ED, Malhi SS, Nyborg M, Gill KS (2005) Temperature, soil moisture, and antecedent sulfur application effects on recovery of elemental sulfur as SO4-S in incubated soils. Commun Soil Sci Plant Anal 36:863-874

Sverdrup H, Belyazid S, Nihlgård B, Ericson L (2007) Modelling change in ground vegetation response to acid and nitrogen pollution, climate change and forest management at in Sweden 1500 2100 AD. Water Air Soil Pollut Focus 7(1-3):163-179

Tabatabai MA (1996) Sulfur. Methods of Soil Analysis Part 3. Chemical Methods. Soil Science Society of America, American Society of Agronomy, Madison

Umweltbundesamt (2018) Emissionstrends 1990-2016: Ein Überblick über die Verursacher von Luftschadstoffen in Österreich, Umweltbundesamt GmbH, Vienna

Watmough SA et al (2005) Sulphate, nitrogen and base cation budgets at 21 forested catchments in Canada, the United States and Europe. Environ Monit Assess 109(1-3):1-36

Zhang Y, Mitchell MJ, Christ M, Likens GE, Krouse HR (1998) Stable sulfur isotopic biogeochemistry of the Hubbard Brook experimental forest, New Hampshire. Biogeochemistry 41(3):259-275

Publisher's Note Springer Nature remains neutral with regard to jurisdictional claims in published maps and institutional affiliations. 